\title{
Man is Invincible -- about Hemingway's Humanism
}

\author{
Liangguang Huang \\ English Department, Zhenjiang Watercraft College of PLA \\ Zhenjiang 212003, China \\ E-mail: Blackhawk1975@126.com
}

\begin{abstract}
Hemingway wrote a short story A Day's Wait in 1933, a nine-year old boy spent a whole day waiting for death because of misunderstanding the difference of the Centigrade and Fahrenheit. "Glory under pressure", when facing the death, the little boy would rather stay calmly than do something uncontrollably. In his masterpiece The Old Man and the Sea, an old fisherman, Santiago tried his best to catch a giant marlin, and then he fought with packs of sharks when he returned home, which almost exhausted all his strength. Whether in his short story or masterpiece, whether the little boy or the old man, when they faced the crisis, they showed the great encourage. A man can be destroyed, but not be defeated.
\end{abstract}

Keywords: Hemingway, The old man, Struggle, Undefeated

In the two years following the publication of For Whom the Bell Tolls in 1940, Hemingway travelled in China as a war correspondent writing reports about the Anti-Japanese War for a New York newspaper. His participation in the Second World War might have provided more experience for him but deprived him of time for writing, so that it was ten years after the publication of For Whom the Bell Tolls that the novel Across the River and Into the Trees (1950) came out, which has received many unfavorable opinions.

As if Hemingway would defend his reputation and win back his honor as a great writer, two years later he published The Old Man and the Sea, which proved to be a great success. Like Santiago who had captured the greatest marlin, Hemingway achieved great success for which he won the Pulitzer Prize, and in 1954, the Nobel Prize for Literature.

The novel was based on one of his early fishing article for a magazine in the thirties, which told about an old fisherman who caught a giant marlin and lost it in the mouths of sharks. "He was crying in the boat when the fishermen picked him up, half crazy from his loss and the sharks were still circling the boat." This description is apparently different from The Old Man and the Sea, which is about how an old fisherman fights against his old age and his ill luck as well as against a marlin which is almost too big and too powerful for his strength.

The story has received many different explanations since its publication. For some critics the story symbolizes the author's own struggle in his writing career. The old man was once the champion and now is growing old, his reputation is in peril, but he believes that he still has strength and skill to win victory.

Some critics explain the story as Christian tragedy or allegory and have dug out many Christian symbols:

"Three, seven and forty are key numbers in the Old and New Testaments, and in the religion, and Hemingway makes a judicious use of them. The old man has fished alone for forty-four famine days and with the boy for forty more. The Old Man's trial with the great fish lasts exactly three days; the fish is landed on the seventh attempt; seven sharks are killed and although Christ fell from the weight of the mast seven times; there is a consistency in the equal importance of the numbers themselves."

The mast Santiago carries up the hill resembles the Cross, when he lies in bed sleeping, he assumes the posture of the crucifix. His cry "Ay" is "just such a noise such as a man might make, involuntarily, feeling the nail go through his hands and into the wood."

Were the Christian symbols with such prominence meant to transform the story into a Christian allegory or Christian tragedy? After finishing the novel the author said the novel had everything in it he had believed in; "that he had got finally what he had been working for all his life." We can't help asking what he had been working for all his life. Was Christian what concerned his most in his life?

Many of his heroes do pray automatically or habitually at the moment of crisis or despair, but they are never religious and never really dependent on God's salvation or assistance.

Santiago too, after twenty-four hours of desperate struggle with the great fish, prays for heavenly assistance, meanwhile he thinks to himself "I am not religious." After the great marlin has been eaten by sharks, he believes that it is because he has gone out too far, instead of blaming God or Mary, for their failure to assist, the old man 
is too proud to depend on God.

To Hemingway, man can not turn to God for help; man must depend on himself; submission to God's will is not in agreement with Hemingway's principle, so in spite of many Christian symbols interwoven in the story, the symbols may not be meant to transform the story into a Christian allegory but may serve to elevate Humanism to the height of religion - the religion of Man. The story can be called a humanist allegory which stands for man's continuous struggle with the external world under unfavorable conditions to defend man's dignity and to show man's intelligence, courage, endurance and invincibility; the story can be regarded as hymn of man or an expression of the author's strong belief - Humanism.

Santiago's struggle with his fate takes two steps: first fighting with the great marlin and then with sharks. He fights with the marlin with honor and sympathy; but with malignancy he fights with the sharks that come to rob the old man of his prize, of his pride and honor. For all the two different attitudes he fights him with one great determination: to defend his dignity as an invincible man.

The old man fights with the big marlin not from antagonism. He has deep love and sympathy for all creatures: dolphin, birds, turtles and the great marlin he is trying to kill. Once he caught one of a pair of marlin: the male fish followed the hooked female all the way, and even jumped high into the air to see where his companion was when the female was hoisted into the boat. The old man thinks that was the saddest thing he had ever seen. The old man's love for the marlin is also sincere. "Fish, I love you and respect you very much. But I will kill you dead before this day ends." He will kill the fish in "all his greatness and his glory".

Making money is not the main reason to kill the fish either, although he can hardly keep his life going for lack of money and he calculates the money the great fish will bring to him. He declares that he doesn't kill the fish just to sell for food. "You killed him for pride and because you are a fisherman".

His imperative to win is more important than material necessity.

Fighting with the great fish is also a good test of man's power of endurance. "Pain does not matter to a man".

The old man's power of endurance is carefully depicted, proved and tested step by step.

Santiago is old, thin, gaunt and wrinkled, but he is still dauntless, unyielding and self-confident. His eyes, the mirrors of his soul, still reflect the light of the young and have the same color as the sea and are "cheerful and undefeated". His shoulders and neck are powerful and strong.

Santiago hadn't caught anything for eighty-four days due to his "ill-luck"; some young fishermen joked about him; the boy, Manolin, who had worked with him, was taken away from him but he bore the ill luck and humiliation in silence and "His hope and his confidence had never gone. But now they were freshening as when the breeze rises."

On the eight-fifth day his luck seems to favor him with the great marlin hooked, but the fish proves to be big and powerful that it tows the boat slowly off the coast and starts with the trying journey, or competition of endurance. The old man tries not to think but endure with the determination to conquer the fish alone. During the night the fish jerks, pulling down the old man and cutting his face.

On the second morning, the fish surges and the line makes a deep cut in the old man's hand. Stiff and hungry, the old man eats raw fish to procure some strength and recalls his victory over the strong Black in the hand wrestling, to bolster him to endure. All the afternoon and again into the night the fish goes on, and during the night the marlin jumps again, cutting the old man's wounded hands which are raw and bleeding.

On the third morning, the fish begins a series of leaps, almost cutting through the old man's hand and the pain from the cord across his back has passed pain and gone into a dullness that he "mistrusted". "Tired deep into his bones", he has been seeing black spots in front of his eyes for an hour; he is wet with sweat which salts his eyes, and the cut over the eye and on his forehead; he feels "faint and dizzy" thinking to himself that he must hold the pain of the fish and the pain will drive the fish mad but he can control his own pain.

Now it is time to pull on the fish and he is tired than he has ever been. Feeling faint again, he prays to himself "Pull, hands, Hold up, legs. Last, for me, head." The fish who is pulled part way then "rights himself and swims away" and the old man now worried that he is not good for many turns. "Fish, you are going to have to die anyway. Do you have to kill me too?" Feeling confused in the head, he orders himself "Keep your head clear and know how to suffer like a man." After the fish makes a few more turns, the old man is "on the point of feeling himself go" and can only see well in the flashes. By the time he drives his harpoon into the fish's heart, he has almost lost consciousness. At last the competition ends in the old man's success. The whole process of catching the fish is a presentation of what man can do and what a man endures. 
In order to show his invincibility, the old man fights not only with endurance but also with resolution or even desperation. Hemingway once wrote a story The Undefeated which shows how Manuel, the matador, fought the strong bull, attacking it many times but until he stuck his sword into the bull's heart to win his honor. Now the old man is confronted with the same crisis as Manuel in "The undefeated; both the bull Manuel is attacking and the great marlin Santiago is trying to catch prove to endanger their lives but both Manuel and Santiago are too proud to give up and accept their failure. At the last moment the old man is on the point of dying, "You are killing me, fish, but you have a right to. Never have I seen a greater, or more beautiful or a calmer or more noble thing than you, brother. Come on and kill me. I do not care who kills who." The old man faces the threat of death without wavering in his determination to conquer.

In Hemingway's novels there are many different deaths: the death of soldiers, the death of bulls, horses, fish, ants and the deaths are endowed with various meanings. Now the death the old man confronts is the touch stones of endurance and determination to conquer. His eight-four days failure to catch a fish and the three days torture deprive the old man of almost everything, living necessities, strength, except his pride and dignity. He would rather die than live as a failure. He says to the fish "I'll stay with you until I am dead". It is desperation to keep his dignity as an invincible man that cuts off all means of retreat; that forces the old man to tighten the line to follow the fish anywhere the fish will go, regardless of anything that should happen; that helps the old man to win the victory over the great fish. The dying fish which rises high out of the water but "with death in him" proves that man is king and man is invincible.

After much "slave work" of lashing the fish to the boat, the old man is destined to have another fight, the fight with sharks to protect his hard won prize and honor. Now it is no longer an ordeal he has to stand to achieve his triumph, put catastrophe he has to meet with. The old man kills the first shark, which sinks with the harpoon in his body and then he has to resort to all kinds of make-shift means to fight the sharks. At last the sharks come in a pack at midnight and all the hope of preserving the fish is gone, but the old man still clubs at the sharks desperately. When the club is gone, he uses the tiller; when the tiller breaks, he employs the splintered butt to fight until the great fish is completely eaten up and the last shark rolls away.

The old man fights the useless struggle without any hope to win but with more heroism. He knows man must struggle against defeat. "Man is not made for defeat ... A man can be destroyed but not defeated." The preservation of his dignity lies not in material victory but in his unyielding struggle and in his determination to fight to the end of his life. The great fish is lost but the old man's invincible spirit and dignity are preserved.

The lion image in the novel has caused many controversies. The lions are not only a recurring image in the old man's dream but also what he wishes to see in his dreams. At the end of the novel again "the old man was dreaming about lions". Clinton S, Burhans, JR. says "It seems also significant that the old man no longer dreamed of storms, nor of women, nor of great occurrences, nor of great fish, nor fights nor contests of strength nor of his wife - that is that he no longer dreamed of great individualistic deeds like the one which brings violence and destruction on him and on the marlin. Instead, the lions are 'the main thing that is left', and they have evoked the solidarity and love and peace to which the old man returns after hunting and killing and losing his great fish".

Some critic says "the lions of the dream are as lions have always been, an emblem of life at its strongest and finest, suggesting youth, great deeds, sometimes wonderful to dream about and to long to return to, to possess again".

I think it seems rather difficult to relate the lions to solidarity, love and peace. It is impossible for the old man to dream of peace and love in a life and death struggle with the great fish.

If the lions are "an emblem of life at its strongest suggesting youth, great deeds, sometimes to dream about." it is easy for the old man to stay at home to dream about them and enjoy his past glory. In the past he was a champion fisherman but the past victory "meant nothing". "Each time was a new time and he never thought about the past" and he is eager to prove his strength and power each time. Storms, women, great occurrences, hand wrestling, great fish, and his wife all symbolize his past experiences or his past glory which he won't hold fast, since he is the man who never thinks of the past when he is proving his strength, his honor.

I think it is better to explain the lions as symbols of invincibility, dignity and courage, which are what concern the old man most and he tries his best to prove, since the lion is generally regarded as king of beasts with the impression of supremacy and invincibility.

On the second day of his fight with the great fish, the old man's hand cramps and the line has cut his hand and face. The old man prays and recalls the hand wrestle he won years ago to encourage himself; meanwhile he 
wishes he could sleep and dream about lions. Why? I think the lion symbol can play the same effect as hand wrestling - to bolster and help him to endure.

At the end of the novel "the old man was dreaming about lions" which means that in spite of his temporary loss he has not lost confidence in himself. His invincible spirit and dignity remain untouched.

The baseball match, in which DiMaggio is the champion, is also an important symbol in the novel. The old man holds high respect for DiMaggio "who makes the difference" and in trying times he encourages himself that he must have confidence and be worthy of the great DiMaggio, who does all things perfectly, even with pain of the bone spur in his heel.

Moreover, the baseball match may suggest the whole process of the old man's struggle. In yesterday's newspaper, the Yankees (DiMaggio's team) won the baseball match and they've lost today. Yesterday's success may parallel the old man's past glorious experiences and today's loss may signify the old man's present failure and bad luck. The old man convinces the boy that DiMaggio's loss means nothing. "The great DiMaggio is himself again," which implies the old man's self-confidence and unyielding spirit. Although the old man has lost his fish he is not really beaten by the shark which he can kill easily as long as he has good weapons "And what beat you?" he thinks aloud, "Nothing," and the reason for his loss is only that he "went out too far." The old man is confident of his ultimate triumph and is prepared to go on with his struggle, while he is still in bed he tells Manolin "We must get a good killing lance and always have it on board." For all his temporary loss the old man will triumph in the long run Man is invincible.

Philip Young says "To take the broadest view, however, the novel is a representation of life as a struggle against unconquerable natural forces in which a kind of victory is possible." To Hemingway, perhaps the world and natural forces are not "unconquerable"; with all his wisdom and intelligence, endurance and fortitude, man will win his final victory; as the humanists of the 16th-century believed "Man could mould the world according to his desires and attain happiness by removing all external checks by the exercises of human intellect."

The story is like a hymn of man once sung by Hamlet. "What a piece of work is a man! How noble in reason! How infinite in faculty! In form and moving how express and admirable! In action how like an angel in apprehension how like a god!" In fact, Hemingway added more meanings to the hymn of man "Man is not made for defeat; A man can be destroyed but not defeated."

Ernest Hemingway took part in two world wars, he would have not survived if he did not conquer great trouble. So whether in his short stories or in his novels, he wrote about death. When facing with the death, a real man should try his best to defeat it, because Man is Invincible.

\section{References}

David Lodge. (2002). Analysis and Interpretation of the Realist Text: Ernest Hemingway's "Cat in the Rain"[C]. Beijing: Foreign Language Teaching and Research Press.

Ernest Hemingway. [Online] Available: http://www.nichecreator.com/popvideo/index.php?k=Ernest_Hemmingway\#External_links

Liu, Ying. (2005). Hemingway's use of Language in Hills Like White Elephants. Journal of Urumqi Vocational and Technical University.

Li, Yixie and Chang, Yaoxin. (1991). Selected Readings in American Literature[C]. Henry James. The Ambassadors. Tianjin: Nankai University Press.

Meyers, Jeffrey. (1985). Hemingway: A Biography. London: Macmillan.

Mellow, James R. (1992). Hemingway: A Life without Consequences. New York: Houghton Mifflin.

Oliver, Charles M. (1999). Ernest Hemingway A to Z: The Essential Reference to the Life and Work. New York: Checkmark. 